Estudio preliminar de las preferencias de hábitat del venado temazate rojo

(Mazama temama) en una región montañosa del centro de México

\title{
Preliminary study of habitat preferences of red brocket deer (Mazama temama) in a mountainous region of central Mexico
}

\author{
Luz Adriana Pérez-Solano' ${ }^{1 *}$, Mircea G. Hidalgo-Mihart², and Salvador Mandujano
}

\begin{abstract}
${ }^{1}$ Red de Biología y Conservación de Vertebrados, Instituto de Ecología A. C. Carretera Antigua a Coatepec 351, El Haya, 91070. Xalapa, Veracruz, México. Email: adriana.perez.s@outlook.com (LAP-S), salvador.mandujano@inecol.mx (SM)

2División Académica de Ciencias Biológicas, Universidad Juárez Autónoma de Tabasco. Km 0.5 Carretera Villahermosa-Cárdenas 86039. Villahermosa, Tabasco, México. Email: mhidalgo@yahoo.com (MGH-M)

*Corresponding author
\end{abstract}

The red brocket deer (Mazama temama) is a cervid distributed throughout Mexico and Central America. There is limited availability of information regarding this species, especially in the mountainous ranges typical of its geographical distribution. In this scientific note we present preliminary results of the habitat preferences of the red brocket deer in the highlands of the Mexican states of Puebla, Oaxaca, and Veracruz. We evaluated the habitat use-availability of the red brocket in relation to four habitat variables (vegetation type, vegetation cover, plant species richness and slope). We considered the presence of signs (tracks, scats or direct sightings) as an indicator of use, while availability was evaluated with points every $500 \mathrm{~m}$. We used chi-squared tests in combination with Bonferroni confidence intervals to determine whether the red brocket preferred or avoided the selected habitat variables. Results showed that the red brocket selected croplands (coffee agroecosystems) and avoided areas covered by secondary growth vegetation. We observed that the species selects sites with high vegetation cover and intermediate plant species richness. It has been reported that the red brocket is commonly found in areas with little human influence; our results suggest that this species can also use sites with low-level disturbance, such as coffee agroecosystems. However, the use of these sites is associated with the proximity of patches of vegetation in good condition (Bodmer 1989; Lira-Torres and Naranjo 2003). The results of our study contribute to understanding how this species responds to the habitat characteristics of its environment. This information will help to develop appropriate conservation and management plans to maintain healthy populations of the species.

El venado temazate rojo (Mazama temama) es una especie de cérvido que se distribuye en México y Centro América. Se tiene muy poca información de esta especie, principalmente en las áreas montañosas de su distribución geográfica. En esta nota científica presentamos resultados preliminares de las preferencias de hábitat del temazate rojo en una región serrana de México, localizada en los estados de Puebla, Oaxaca y Veracruz. Evaluamos el uso-disponibilidad del hábitat del temazate rojo en relación a cuatro variables de hábitat (tipo de vegetación, cobertura vegetal, riqueza de especies vegetales y pendiente del terreno). Consideramos la presencia de señales (huellas, excrementos o avistamientos directos) de temazates como un indicador de uso, mientras que la disponibilidad fue evaluada mediante puntos cada $500 \mathrm{~m}$. Usamos pruebas de chi cuadrada en combinación con intervalos de confianza de Bonferroni para determinar la preferencia o evasión de las variables de hábitat que seleccionamos. Los resultados mostraron que los temazates seleccionan cultivos (agroecosistemas cafetaleros) y rechazan sitios de vegetación secundaria. Así mismo, se observó que seleccionan sitios con alta cobertura vegetal y sitios con riqueza vegetal media. Se ha reportado que esta especie comúnmente se encuentra en áreas con baja influencia humana, nuestros resultados sugieren que el temazate rojo también puede hacer uso de sitios con bajos niveles de perturbación, como lo son los cultivos. Sin embargo, el uso de estos sitios está asociado a la cercanía de parches de vegetación en buen estado de conservación (Bodmer 1989; Lira-Torres y Naranjo 2003). Los resultados de nuestro estudio ayudan a entender cómo la especie responde a las características de su hábitat. Esta información es relevante para la conservación y medidas de manejo que ayuden a mantener poblaciones sanas de este cérvido.

Key words: Central American red brocket; cervid; conservation; habitat use; Mazama; montane cloud forest.

๑ 2016 Asociación Mexicana de Mastozoología, www.mastozoologiamexicana.org

\section{Introduction}

Deer species of the genus Mazama constitute the least-studied group of cervids in Latin America. The Central American red brocket (Mazama temama Kerr 1792) has been classified as a habitat specialist (Weber 2008). In general, high quality habitat for a brocket deer has been considered to be 
characterized by the availability of water sources, dense understory vegetation and low human hunting pressure (Rivero et al. 2005; Di Bitetti et al. 2008; Weber 2008). In habitats where the dominant vegetation is temperate forest, Lira-Torres and Naranjo (2003) reported that red brocket deer prefers cloud forests combined with secondary growth vegetation, compared to areas exclusively of cloud forest or coffee plantations. However, these authors reported in the same study that the highest relative abundance occurs in places where cloud forest was the dominant vegetation.

The red brocket deer (M. temama) has the largest distribution of the two species that belong to the Mazama genus in Mexico, ranging from southern Tamaulipas, Mexico, to northern Colombia. It has been reported that this species lives in tropical evergreen forest as well as in montane cloud forest. In some cases, the species inhabits temperate areas such as pine-oak forest (Bello et al. 2010). Studies of this species of brocket deer in montane cloud forests (1,000 and 2,000 m) have been limited to descriptions of diet, their record within taxonomic lists of species and the historical record of the presence of the species throughout these areas (e. g. Hall 1981; VillarrealEspino et al. 2008, Pérez-Solano et al. 2012). In the case of habitat use, evaluation has focused on a large-scale determination of the manner in which red brocket deer use different vegetation types and their population abundance within these types (e. g. Lira-Torres and Naranjo 2003; Reyna-Hurtado and Tanner 2005; 2007). In order to contribute to understanding how this species responds to the characteristics of its immediate habitat, this study presents preliminary results of the habitat preferences of the Central American red brocket deer in a mountainous region of central Mexico.

\section{Material and methods}

We conducted this study in seven sites along a mountain range that covers the states of Veracruz, Puebla, and Oaxaca, Mexico. These areas together constitute a portion of the Sierra Madre del Sur, one of the three main mountain ranges of Mexico. The main vegetation types present are coniferous forest and montane cloud forest.

In this study, we conducted a habitat use and availability analysis in terms of red brocket deer habitat preferences (Johnson 1980). With the help of local guides, we explored sites where red brocket deer have been reported by the local authorities. This fieldwork was conducted from November 2010 to February 2011 at seven sites within the study area (Figure 1). We searched intensively in selected transects for signs of the presence of red brocket deer in each of the study sites. The complicated topographic relief of the study sites (where slopes of terrain can reach over $80^{\circ}$ ), the size of the sites and the willingness of local authorities to allowed us access to the areas, prevented having transects with the same length. Consequently, transects were of variable length, ranging from $2-6 \mathrm{~km}$ (mean $=3.6 \mathrm{~km}, \mathrm{SE}=1.6)$.

The presence of red brocket deer records (tracks, scats or direct sightings) was considered evidence of the use of the habitat by the species at that particular site. We only considered signs that were found at least $300 \mathrm{~m}$ apart from other signs. We characterized the local habitat around the records, based on four variables that other studies have considered important for the presence of the species, such as vegetation type, vegetation cover below $50 \mathrm{~cm}$ in height, plant species richness and slope (See Table 1; Reyna-Hurtado and Tanner 2005; Villarreal-Espino et al. 2008; Bello et al. 2010). In order to determine habitat availability, we decided to conduct a systematic characterization of habitat every $500 \mathrm{~m}$, the characterization of these points was the same as that in the habitat use records. The location of these points was independent of the presence or absence of red brocket deer signs. This method is adapted to the estimation method proposed by Marcum and Loftsgaarden (1980). 


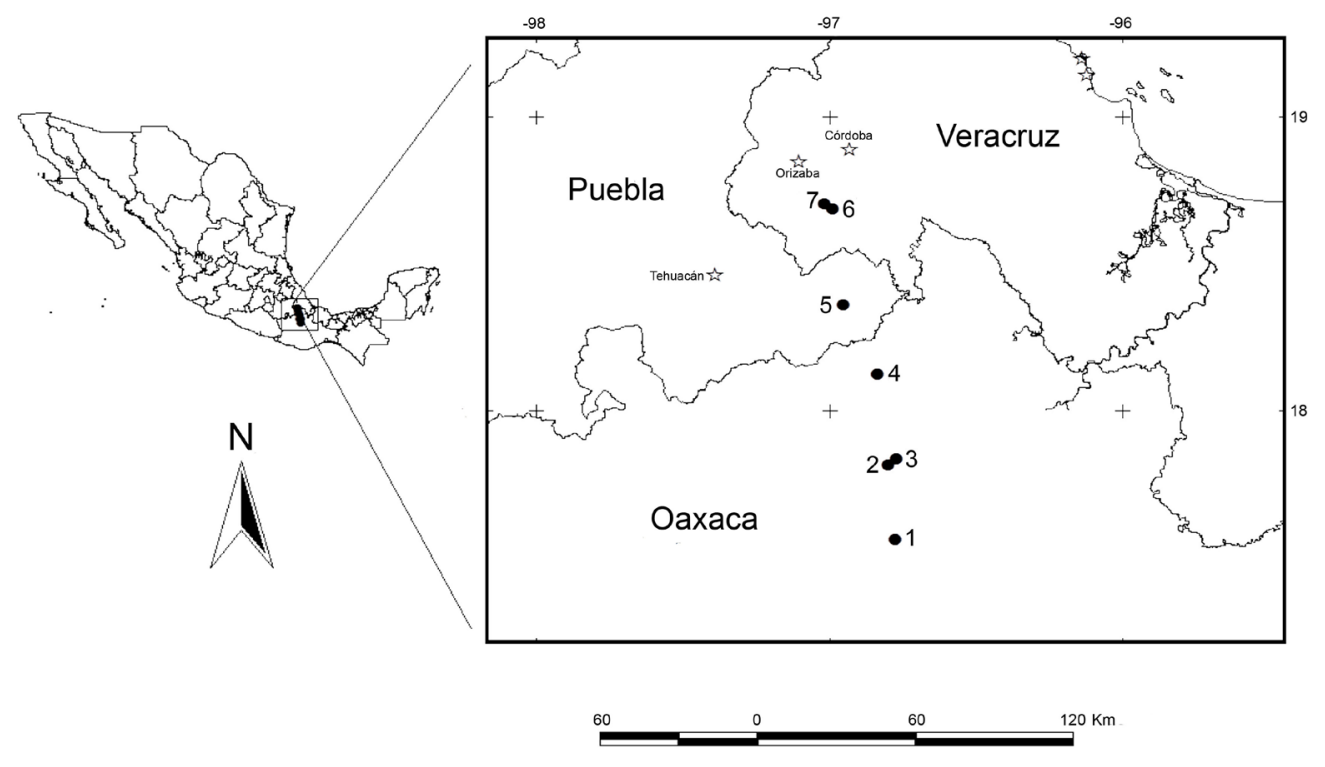

Figure 1. Map of the study area, indicating the study sites. The numbers indicate the name of each site. (1) San Juan Bautista Atatlahuca, Oaxaca. (2) Ojo de Agua, Santa Ma. Pápalo, Oaxaca. (3) Cerro Temazate, Santa Ma. Pápalo, Oaxaca. (4) Huautla de Jiménez, Oaxaca. (5) Xaltepec, Zoquitlán, Puebla. (6) Tlaixco, Zongolica, Veracruz. (7) Atempa de los Reyes, Los Reyes, Veracruz.

In order to perform the use-availability analysis, the four habitat variables were divided into four or five categories, depending on the characteristics of each variable (Table 1). We analyzed habitat use-availability by performing a chi-squared test with Bonferroni confidence intervals at $95 \%$ (Neu et al. 1974; Byers et al. 1984).

\section{Results}

We obtained 52 records of red brocket deer habitat use and recorded 30 points of habitat availability. We did not obtain a sufficient number of records for each of the studied sites, and the analyses were therefore performed combining the data from all seven sites. Significant differences were found between the habitat use-availability for the four measured variables (Table 2). The Bonferroni confidence intervals indicate that the main differences between use and habitat availability occurred in the variables vegetation type, vegetation cover below $50 \mathrm{~cm}$ in height and plant species richness. In the vegetation type variable, the red brocket deer selected sites with coffee agroecosystems and avoided secondary growth vegetation. The other vegetation types were used according to availability. With respect to vegetation cover below $50 \mathrm{~cm}$ in height, the species selects sites where this kind of vegetation was very dense, in ranges from 76 to $100 \%$. In the case of plant species richness, the species selects sites categorized with an intermediate number of plant species ( 6 to 13 species) while avoiding sites with either low (1 to 5 species) or high (14 to 17 species) plant species richness. Slope did not show any effect since the red brocket deer used each category according to availability in its habitat.

\section{Discussion}

Studies carried out with the red brocket deer (M. americana) of South America show that this species is commonly found in areas that present little human influence (Weber and González 2003). Our results suggest that the red brocket deer (M. temama) that inhabit the mountainous region of Mexico can also use areas covered with croplands, such as coffee agroecosystems. The use of such areas by the species has been reported in other studies, but has invariably been associated with the proximity of well-preserved sites (Lira-Torres and Naranjo 2003). 
Table 1. Habitat variables characterized from records and points of availability habitat of red brocket deer (Mazama temama) in seven sites along a portion of the Sierra Madre del Sur, that covers the states of Veracruz, Puebla, and Oaxaca, Mexico. The importance of the variable characterized for brocket deer is indicated, along with a description of how the variable was measured, and the categories into which the variable was divided.

\begin{tabular}{|c|c|c|c|}
\hline Habitat variables & Importance & Categories & $\begin{array}{c}\text { Identification of the category and } \\
\text { description of how the variable was } \\
\text { measured }\end{array}$ \\
\hline \multirow[t]{5}{*}{ Vegetation Type } & \multirow{5}{*}{$\begin{array}{l}\text { An indicator of the red brocket deer } \\
\text { response to the climate present in } \\
\text { the area, altitude above sea level and } \\
\text { the characteristics of the topography } \\
\text { surrounding the site where the species } \\
\text { was recorded. Vegetation type also } \\
\text { allows a quick determination of tree cover } \\
\text { characteristics as well as human impact. }\end{array}$} & Cloud forests & $\begin{array}{l}\text { Presence of trees of genus Liquidambar, } \\
\text { Magnolia, Pinus and Quercus. Presence of } \\
\text { large numbers of epiphytes, ferns, and vines. }\end{array}$ \\
\hline & & Pine-Oak forests & $\begin{array}{l}\text { Dominance of coniferous trees or in } \\
\text { combination with oaks (Quercus sp.). }\end{array}$ \\
\hline & & Riparian forests & $\begin{array}{l}\text { Nearby presence of rivers, streams and } \\
\text { floodplains. }\end{array}$ \\
\hline & & $\begin{array}{l}\text { Secondary growth } \\
\text { vegetation }\end{array}$ & $\begin{array}{l}\text { Areas in a process of recovery where natural } \\
\text { vegetation was removed from two to ten } \\
\text { years ago. }\end{array}$ \\
\hline & & Croplands & $\begin{array}{l}\text { Agro ecosystems of shaded coffee, } \\
\text { surrounded by cloud forests. }\end{array}$ \\
\hline $\begin{array}{l}\text { Understory vegetation } \\
\text { cover below } 50 \mathrm{~cm} \text { in } \\
\text { height (\%) }\end{array}$ & $\begin{array}{l}\text { The vegetation below } 50 \mathrm{~cm} \text { in height } \\
\text { is used by the red brocket deer for } \\
\text { protection. Likewise, brocket deer diet is } \\
\text { based on herbaceous plants found in this } \\
\text { stratum (Villarreal-Espino et al. 2008). }\end{array}$ & $\begin{array}{c}0-25 \\
26-50 \\
51-75 \\
76-100\end{array}$ & $\begin{array}{l}\text { Within a radius of } 3 \mathrm{~m} \text { around the record, we } \\
\text { calculated the percentage of the total area } \\
\text { covered by grass and shrub vegetation below } \\
50 \mathrm{~cm} \text { in height. To avoid bias, all estimations } \\
\text { were performed by the same person. }\end{array}$ \\
\hline $\begin{array}{l}\text { Plant richness (Number } \\
\text { of species) }\end{array}$ & $\begin{array}{l}\text { The number of plant species is an indicator } \\
\text { of the degree of conservation of the site, } \\
\text { as well as the potential for finding food. }\end{array}$ & $\begin{array}{c}1-5 \\
6-9 \\
10-13 \\
14-17\end{array}$ & $\begin{array}{l}\text { Within a radius of } 5 \mathrm{~m} \text { around the record, } \\
\text { we counted the total tree and shrub species } \\
\text { present in the area. }\end{array}$ \\
\hline Slope $\left(^{\circ}\right)$ & $\begin{array}{l}\text { The red brocket deer more commonly uses } \\
\text { steeper slopes of the terrain. }\end{array}$ & $\begin{array}{l}0-21 \\
22-43 \\
44-64 \\
65-85\end{array}$ & $\begin{array}{l}\text { Slope was determined using a clinometer and } \\
\text { taking the site of the brocket recording as the } \\
\text { central point of measurement. }\end{array}$ \\
\hline
\end{tabular}

Interestingly, the time of year (winter season) in which the field sampling was conducted corresponded with the fruiting of coffee plants. Red brocket deer may be using the coffee fruit as a food source. The red brocket is known to be a highly frugivorous species (Gayot et al. 2004; Weber 2008). It has also been found that coffee agroecosystems in the Sierra Madre Oriental of Mexico allow the persistence of an elevated diversity of mammal species, and these systems have been considered key elements for maintaining the regional biodiversity (Gallina et al. 1996). However, specific studies are required in order to fully understand how the brocket deer utilize these human altered environments.

Dense understory vegetation cover is a habitat attribute that has been associated with the presence of several deer species. Vegetation cover is an important feature for basic activities such as rest, shelter, parental care and feeding, as well as providing protection against predators (Villarreal 1999). For the red brocket deer, selection of sites with dense understory vegetation seems essential for survival in the mountainous terrain of our study area. This could be associated with an escape strategy or as a refuge from predation or hunting by local inhabitants. Alternatively, selection of a dense understory vegetation cover below $50 \mathrm{~cm}$ in height could be related to the feeding habits of the species. Villarreal-Espino et al. (2008) analyzed the diet of the species in a montane site in the Mexican state of Puebla and found that their diet consists mainly of shrubs and, to a lesser extent, pastures and oak acorns.

Our results show that the red brocket selects sites of intermediate plant species richness and rejects sites with either very low or very high plant species richness. This choice of selecting 
Table 2. Results of the comparison between the use and availability of the different variables measured in the red brocket deer (Mazama temama) habitat in seven sites along a portion of the Sierra Madre del Sur, that covers the states of Veracruz, Puebla, and Oaxaca, Mexico. Values obtained are shown in the chi-squared test and the Bonferroni confidence intervals.

\begin{tabular}{|c|c|c|c|c|c|c|c|}
\hline Variable & $\begin{array}{l}\text { Chi- } \\
\text { squared } \\
\text { test }\end{array}$ & Categories & $\begin{array}{c}\text { Ratio of } \\
\text { observed }\left(p_{i}\right) \\
(n=52)\end{array}$ & $\begin{array}{l}\text { Expected } \\
\text { proportion of } \\
\text { use }(n=30)\end{array}$ & & $\begin{array}{l}\text { nferron } \\
\text { ifidenc } \\
\text { tervals }\end{array}$ & \\
\hline \multirow[t]{5}{*}{ Type of vegetation } & \multirow{5}{*}{$\begin{array}{c}X^{2}=96.12 \\
P<0.001 \\
\text { d. f. }=4\end{array}$} & Cloud forest & 0.17 & $0.10(=)$ & 0.03 & $\leq p_{i} \leq$ & 0.30 \\
\hline & & Pine-Oak forest & 0.23 & $0.26(=)$ & 0.08 & $\leq p_{i} \leq$ & 0.38 \\
\hline & & Riparian Vegetation & 0.21 & $0.26(=)$ & 0.06 & $\leq p_{i} \leq$ & 0.35 \\
\hline & & $\begin{array}{l}\text { Secondary growth } \\
\text { vegetation }\end{array}$ & 0.19 & $0.33(-)$ & 0.05 & $\leq p_{i} \leq$ & 0.33 \\
\hline & & Croplands & 0.19 & $0.03(+)$ & 0.05 & $\leq p_{i} \leq$ & 0.33 \\
\hline \multirow{4}{*}{$\begin{array}{l}\text { Understory } \\
\text { vegetation cover } \\
\text { below } 50 \mathrm{~cm} \text { in } \\
\text { height }(\%)\end{array}$} & \multirow{4}{*}{$\begin{array}{c}X^{2}=34.27 \\
P<0.001 \\
\text { d. f. }=3\end{array}$} & 0 a 25 & 0.13 & $0.20(=)$ & 0.01 & $\leq p_{i} \leq$ & 0.25 \\
\hline & & 25 a 50 & 0.17 & $0.23(=)$ & 0.04 & $\leq p_{i} \leq$ & 0.30 \\
\hline & & 51 a 75 & 0.07 & $0.16(=)$ & -0.01 & $\leq p_{i} \leq$ & 0.16 \\
\hline & & 76 a 100 & 0.61 & $0.40(+)$ & 0.44 & $\leq p_{i} \leq$ & 0.78 \\
\hline \multirow{4}{*}{$\begin{array}{l}\text { Plant richness } \\
\text { (Number of species) }\end{array}$} & \multirow{4}{*}{$\begin{array}{c}X^{2}=148.76 \\
P<0.001 \\
\text { d. f. }=3\end{array}$} & 1 a 5 & 0.15 & $0.50(-)$ & 0.02 & $\leq p_{i} \leq$ & 0.27 \\
\hline & & 6 a 9 & 0.42 & $0.26(=)$ & 0.25 & $\leq p_{i} \leq$ & 0.59 \\
\hline & & 10 a 13 & 0.23 & $0.03(+)$ & 0.08 & $\leq p_{i} \leq$ & 0.37 \\
\hline & & 14 a 17 & 0.19 & $0.53(-)$ & 0.05 & $\leq p_{i} \leq$ & 0.32 \\
\hline \multirow[t]{4}{*}{ Slope $\left({ }^{\circ}\right)$} & \multirow{4}{*}{$\begin{array}{l}X^{2}=34.83 \\
P<0.001 \\
\text { d. f. }=3\end{array}$} & 0 a 21 & 0.36 & $0.50(=)$ & 0.19 & $\leq p_{i} \leq$ & 0.53 \\
\hline & & 22 a 43 & 0.17 & $0.16(=)$ & 0.04 & $\leq p_{i} \leq$ & 0.30 \\
\hline & & 44 a 64 & 0.23 & $0.23(=)$ & 0.08 & $\leq p_{i} \leq$ & 0.37 \\
\hline & & 65 a 85 & 0.23 & $0.10(=)$ & 0.08 & $\leq p_{i} \leq$ & 0.37 \\
\hline
\end{tabular}

Note: the signs (+), (=) and (-) indicate the proportion of use of the particular category according to availability. (+) used more than was available, $(=)$ used according to availability and (-) used less than was available in the habitat.

areas with intermediate plant species richness may be related to the environmental characteristics of the vegetation type in which the species was recorded. According to the intermediate disturbance hypothesis (Connell 1978), areas recovering from an intense disturbance, such as secondary growth vegetation, tend to have an elevated diversity of plant species, while sites in advanced successional stages present lower plant species richness. Based on this observation, the red brocket may reject sites with elevated plant richness because these are secondary growth vegetation sites, but select sites with an intermediate number of species because this is related to areas covered with cloud forest. It is important to note that sites of low plant richness, usually rejected by the red brocket, were associated with areas located near human trails. It has previously been reported that red brocket deer tend to move away from areas that pose a high risk of contact with humans (Lira-Torres and Naranjo 2003; Reyna-Hurtado and Tanner 2005; Di Bitetti et al. 2008).

Our results showed that the red brocket deer does not select any particular category of slope over others. Bello (1993) reports that higher abundances of this species in a tropical evergreen forest were found in rugged terrain with slopes usually ranging from $30^{\circ}$ to $75^{\circ}$. Selection of these areas was related to the persistence of areas of well-preserved forest on these slopes. Data from the category with steeper slopes in our study showed a trend of selection of these sites; however, this trend was not significant. It is possible that an increase in sampling effort would help to clarify the importance of the slope of the terrain as a factor in local-level habitat selection by the brocket in our study area. 
This work represents one of the few studies of red brocket deer habitat at a local scale in a mountain region in Mexico. There is an important and urgent need to increase the availability of data about the red brocket deer, especially considering its ecological importance and significant value to human populations. This information will help to develop the relevant conservation and management measures (such as, for example, the inclusion of some protection status under the Mexican Law) that contribute to maintaining healthy populations of the species.

\section{Acknowledgments}

We would like to thank A. Vázquez for his valuable assistance in the field. This work was supported by the Consejo Nacional de Ciencia y Tecnología (CONACyT) through the Masters scholarship awarded to the first author (Agreement Number 232620). We thank the División de Posgrado and the Red de Biología y Conservación de Vertebrados of Instituto de Ecología, A.C., and the Reserva de la Biosfera TehuacánCuicatlán (CONANP) for their logistical support. This project was financially supported by the CONACyT Project No. CB-2009-01 0000130702 "Interacciones del venado cola blanca y ganado en la RBTC".

\section{Literature Cited}

Bello, J. 1993. Situación actual del orden Artiodactyla en la región de los Tuxtlas, Veracruz. Bachelors thesis. Universidad Veracruzana. Xalapa, México.

Bello, J., R. Reyna-Hurtado, and J. Wilham. 2010. Central American red brocket deer Mazama temama (Kerr 1992). Pp. 166-171 in Neotropical cervidology: Biology and medicine of Latin American deer (Duarte, J. M. B., and S. González, eds.). Jaboticabal, Brasil: Funep and Gland, Suiza, IUCN. São Paulo, Brasil.

Bodmer, R. 1989. Ungulate biomass in relation to feeding strategy within Amazonian forests. Oecologia 81:547-550.

Byers, C. R., K. Steinhorst, and P. R. Krausman. 1984. Clarification of a technique for analysis of utilization-availability data. Journal of Wildlife Management 48:1050-1053.

ConnelL, J. H. 1978. Diversity in Tropical Rain Forests and Coral Reefs. Science 199:1302-1310.

Di Bitetti, M. S., A. Paviolo, C. A. Ferrari, C. De Angelo, and Y. Di Blanco. 2008. Differential Responses to Hunting in Two Sympatric Species of Brocket Deer (Mazama americana and M. nana). Biotropica 40:636-645.

Gallina, S., S. Mandujano, and A. González-Romero. 1996. Conservation of mammalian biodiversity in coffee plantations of Central Veracruz, Mexico. Agroforestry Systems 33:13-27.

Gayot, M. O. Henry, G. Dubost, and D. Sabatier. 2004. Comparative diet of the two forest cervids of the genus Mazama in French Guiana. Journal of Tropical Ecology 20:31-43.

HaLl, E. R. 1981. The mammals of North America. 2th edition. John Wiley and Sons, Inc. New York, EE. UU.

Johnson, D. H. 1980. The comparison of usage and availability measurements for evaluating resource preference. Ecology 61:65-71.

Lira-Torres, I., and E. J. Naranjo. 2003. Abundancia, preferencia de hábitat e impacto del ecoturismo sobre el puma y dos de sus presas en la reserva de la biosfera El Triunfo, Chiapas, México. Revista Mexicana de Mastozoología 7:21-40.

Marcum, C. L., and D. O. Loftsgaarden. 1980. A nonmapping technique for studying habitat preferences. Journal of Wildlife Management 44:963-968. 
Neu, C. W., C. R. Byers, And J. M. Peek. 1974. A technique for analysis of utilization-availability data. Journal of Wildlife Management 38:541-545.

Pérez-Solano, L. A., S. Mandujano, F. Contreras-Moreno, and J. M. Salazar-Torres. 2012. Primeros registros del temazate rojo Mazama temama en áreas aledañas a la Reserva de la Biosfera de Tehuacán-Cuicatlán, México. Revista Mexicana de Biodiversidad 83:875-878.

Reyna-Hurtado, R., And G. W. Tanner. 2005. Habitat preferences of ungulates in hunted and nonhunted areas in the Calakmul forest, Campeche, Mexico. Biotropica 37:676-685.

Reyna-Hurtado, R., AND G. W. Tanner. 2007. Ungulate relative abundance in hunted and nonhunted sites in Calakmul Forest (Southern Mexico). Biodiversity and Conservation 16:743-756.

Rivero, K., D. I. Rumiz, AND A. B. Taber. 2005. Differential habitat use by two sympatric brocket deer species (Mazama americana and M. gouazoubira) in a seasonal Chiquitano forest of Bolivia. Mammalia 69:169-183.

Villareal, J. 1999. Venado cola blanca: manejo y aprovechamiento cinegético. Unión ganadera regional de Nuevo León, México.

Villarreal-Espino, O. A., L. E. Campos-Armendia, T. A. Castillo-Martínez, I. Cortes-Mena, F. X. Plata-Pérez, and G. D. Mendoza-MArtínez. 2008. Composición botánica de la dieta del venado temazate rojo (Mazama temama), en la sierra nororiental del estado de Puebla. Universidad y Ciencia: Trópico Húmedo 24:183-188.

Weber, M., ANd S. GonzÁlez. 2003. Latin American deer diversity and conservation: A review of status and distribution. Ecoscience 10:443-454.

WEBER, M. 2008. Un especialista, un generalista y un oportunista: uso de tipos de vegetación por tres especies de venados en Calakmul, Campeche. Pp. 579-592 in Avances en el estudio de los mamíferos de México II (Lorenzo C., Espinoza E., and Ortega J., eds.). CIBNOR, ECOSUR, IPN, UAEM, UAM, UNICACH, Universidad Veracruzana. Ciudad de México, México.

Submited: October 20, 2015

Reviewed: November 30, 2015

Accepted: January 18, 2016

Associated editor: Rafael Reyna 
204 THERYA Vol.7 (1): 197-203 